\title{
Teknologi Informasi Pada Masyarakat Miskin
}

\author{
Endah Prasetyani
}

Pusdiklat Kementerian Agama

endahprasetyani@gmail.com

Cara Sitasi: Prasetyani. E. (2019). Teknologi Informasi Pada Masyarakat Miskin. Cakrawala, 19(2), $263-266$. Retrieved from doi: https://doi.org/10.31294/jc.v19i2

\begin{abstract}
Information Technology is one component in national development. Even the people already know him and many are skilled in their use. Poverty in every province in Indonesia has different levels. But whether in some communities, especially the poor have been as skilled as the established community. The author uses a research method with a quantitative approach with statistical data analysis methods. And it turns out, regions with high levels of poverty, certainly low levels of mastery of technological skills.
\end{abstract}

Keywords: Provincial, quantitative, mastery of skills

\section{PENDAHULUAN}

Tujuan tulisan ini adalah untuk mengetahui hubungan antara Keterampilan Teknologi Informasi dan Komputer dengan tingkat kemiskinan. Ini sangat penting untuk dikaji karena di era Teknologi informasi dan komunikasi saat ini berkembang secara pesat.

Dalam berbagai aktifitas, kemudahan teknologi Informasi memberikan banyak penawaran untuk menghemat berbagai aspek dan dimensi. Teknologi Informasi menurut Tjai Fung Jin, 2003 adalah tidak hanya terbatas pada proses di komputer saja dalam hal software/hardware saja, tetapi juga pada proses komunikasinya untuk mengirimkan informasi tersebut. Teknologi Informasi dari semula perangkat analog sederhana, maju dan berkembang menjadi digital bahkan real time yang tidak lagi terkendala dengan jarak. Apakah masyarakat miskin yang dalam arti sempit menurut (Humady, 2008) diartikan sebagai suatu keadaan dimana untuk menjamin kelangsungan hidupnya mereka dalam kekurangan uang dan barang, apakah juga sudah terampil dalam pemanfaatannya Teknologi Informasi. Kurniawan, 2004 juga mengatakan bahwa kemiskinan adalah kekurangan dalam hal kebutuhan sosial, dan ketidak mampuan partisipasi dalam kehidupan yang layak.

Hasil dari kajian ini akan bermanfaat untuk mengetahui korelasi antara tingkat kemiskinan dan keterampilan masyarakat dalam penguasaan Teknologi Informasi.

Sepanjang pengetahuan penulis, studi mengenai masalah ini masih sangat terbatas. Beberapa studi lebih banyak pada pembelajaran pendidikan seperti Ismail Darimi, 2017 yang mengangkat tentang TIK sebagai media pendidikan Agama Islam. Juga secara efektif.sebelumnya pernah dilakukan oleh Rila Setyaningsih, 2017 tentang Pengentasan Kemiskinan Perkotaan dalam Teknologi Informasi dan Komunikasi. Hasil studi tersebut menunjukkan bahwa kondisi ekonomi dapat menjadi latar belakang seseorang menjadi punk.

Kajian ini dibatasi pada Propinsi pada Pulau Sumatera saja, karena Pulau Sumatera memiliki beberapa pulau kecil. Juga karena untuk mengetahui tingkat keterampilan dimaksud dibandngkan dengan tingkat kemiskinannya. Penulis menduga bahwa semakin tinggi tingkat kemiskinan, maka semakin rendah pula tingkat keterampilan Teknologi Informasi masyarakat tersebut.

\section{Proporsi Remaja dan Dewasa Usia 15-59 Tahun dengan Keterampilan Teknologi}

Berikut adalah grafik perbandingan proporsi Remaja dan dewasa usia 15-59 tahun yang memiliki keterampilan teknologi.

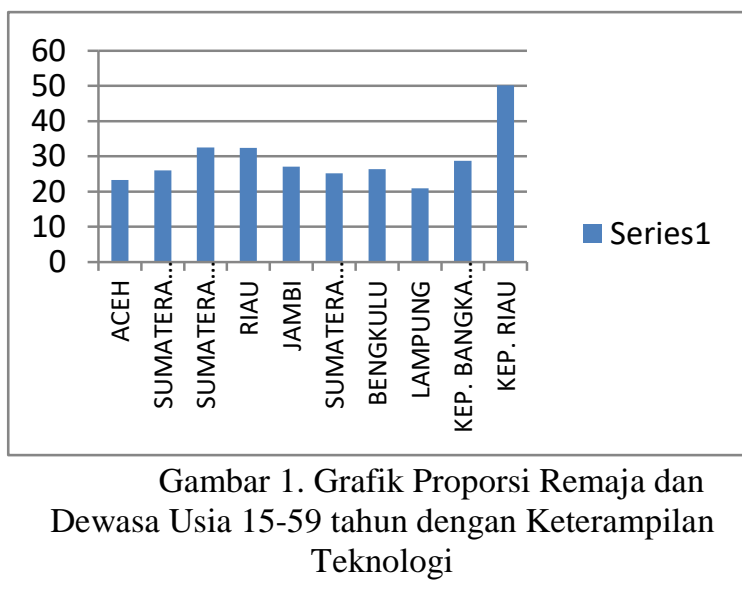

Dari data diatas, terdapat perbedaan yang signifikan antara Lampung dan Kep. Riau. Lampung menempati ranking tertinggi dalam hal penguasaan 
Keterampilan Teknologi, sedangkan Lampung menempati posisi paling rendah dalam hal penguasaan teknologi. Aceh yang merupakan propinsi paling ujung, sama posisinya dengan Lampung adalah berada pada posisi ketiga setelah Lampung.

Ini menggambarkan bahwa propinsi yang berada paling ujung hamper sama keterampilan bidang Teknologi Informasinya.

\section{Prosentase Kemiskinan Pulau Sumatera}

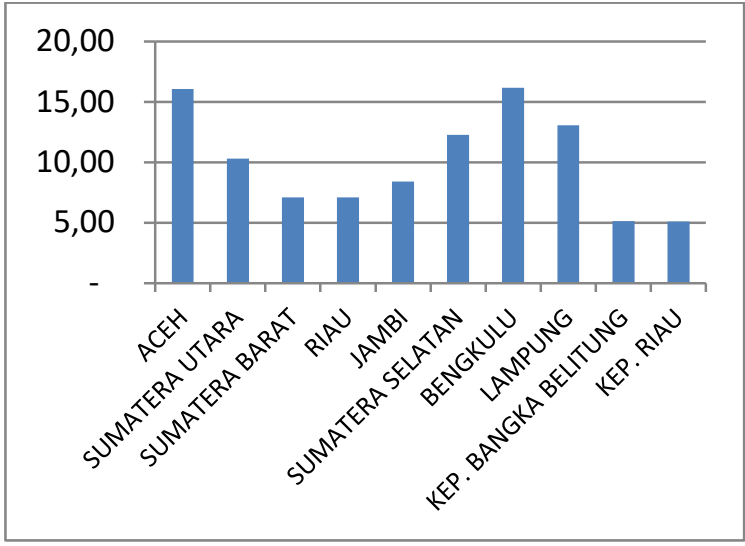

Gambar 2. Grafik Prosentase Kemiskinan

Pulau Sumatera

Grafik diatas menggambarkan adanya peta kemiskinan pada Pulau Sumatera. Pada Kepulauan Bangka dan Belitung memiliki tingkat kemiskinan yang sama dengan Kepulauan Riau. Dan Bengkulu memiliki tingkat kemiskinan paling tinggi.

\section{METODOLOGI PENELITIAN}

Penulis menggunakan metode penelitian dengan pendekatan kuantitaif dengan metode analisis data statistic. Sugiono, 2010 menyatakan bahwa analisis deskriptif merupakan metode yang digunakan untuk mendekripsikan data-data yang telah terkumpul.

Data yang digunakan diperoleh dari Badan Pusat Statistik (BPS). Parameternya datanya pada Proporsi Remaja dan Dewasa usia 15-59 tahun dengan Keterampilan Teknologi dan data Prosentase Kemiskinan. Adapun lokus penelitian hanya pada Propinsi pada Pulau Sumatera saja.

\section{HASIL DAN PEMBAHASAN}

Regresi Linear sederhana digunakan untuk menguji pengaruh antara variable $\mathrm{X}$ dan $\mathrm{Y}$.

$X=$ Remaja dan dewasa usia 15-59 tahun yang memiliki keterampilan teknologi,

$$
\mathrm{Y}=\quad \text { Kemiskinan }
$$

\begin{tabular}{lr}
\hline \multicolumn{2}{c}{ Regression Statistics } \\
\hline Multiple R & 0.666079 \\
R Square & 0.443662 \\
Adjusted R Square & 0.374119 \\
Standard Error & 3.296281 \\
Observations & 10 \\
\hline
\end{tabular}

Berdasarkan tabel output diatas, diketahui nilai koefisien determinasi atau $\mathrm{R}$ square adalah sebesar 0,44. Nilai $\mathrm{R}$ Square tersebut dari pengkuadratan nilai koefisien atau $\mathrm{R}$ Yaitu

$\mathrm{R} \quad \mathrm{x} \quad \mathrm{R}=\mathrm{R}$ Square

$0.66 \times 0.66=0.44$

Besarnya angka koefisien determinasi ( $R$ square) same dengan 44\%. Angka tsb mengandung arti bahwa variabel Remaja dan dewasa usia 15-59 tahun yang memiliki keterampilan Teknologi (x) dan variabel Tingkat Kemiskinan (y) memiliki hubungan moderat, seperti terlihat pada grafik berikut ini :

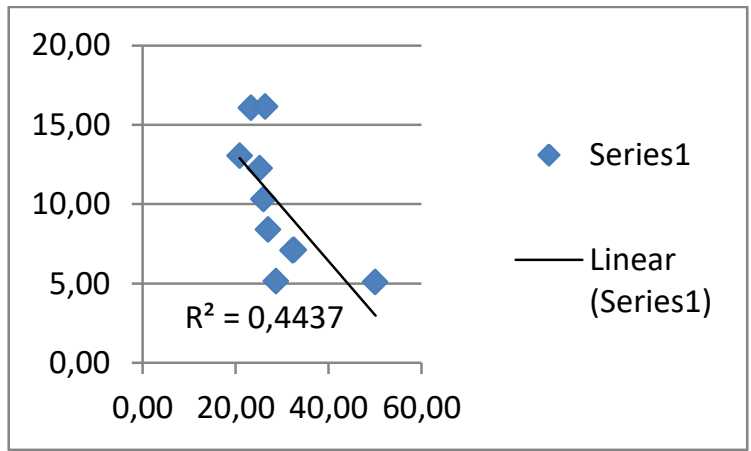

Semakin kecil nilai koefisien determinasi ( $\mathrm{R}$ square), artinya pengaruh variabel bebas (x) terhadap variabel terikat $(\mathrm{Y})$ semakin lemah. Jika $\mathrm{R}$ square semakin mendekati 1, maka pengaruh tersebut semakin kuat.

Grafik diatas menjelaskan, antara $\mathrm{x}$ dan $\mathrm{y}$ terdapat hubungan, tetapi tidak terlalu kuat.

\section{KESIMPULAN}

Dari tujuan tulisan untuk mengetahui hubungan antara Keterampilan Teknologi Informasi dengan tingkat kemiskinan maka didapatkan hasil bahwa daerah yang tingkat kemiskinannya tinggi, pasti tingkat penguasaan keterampilan teknologinya rendah.

Untuk mengatasi hal tersebut, penulis menyarankan untuk dilakukan pemerataan pendidikan khususnya penguasaan keterampilan teknologi bukan hanya di perkotaan saja, melainkan juga di perdesaan. Juga, mengoptimalkan lembagalembaga masyarakat dalam pemberdayaan masyarakat kurang beruntung. 


\section{REFERENSI}

Humady, M. (2008). Pengentasan Rakyat Miskin dan Pembangunan Manusia di Jawa Barat.

Jin, T. F. (2003). Analisis Faktor yang mempengaruhi pemanfaatan teknologi informasi dan pengaruh terhadap kinerja akuntan publik, jurnal bisnis dan akuntansi.

Kurniawan, R. (2004). Poverty Pathology "An Ironic of a Country. Departemen of Governmental Science, Faculty of Social Politics Sciences, University of Lampung.

Sugiyono. (2010). Penelitian Kuantitatif.

\section{PROFIL PENULIS}

Endah Prasetyani. Widyaiswara Kementerian Agama. 
